\title{
Transient Tourniquet and Electro-cauterization applied for Surgery in Metacarpal Fractures Under Local Anesthesia with Epinephrine
}

Ren-Guo XIE ( $\nabla$ renguo.xie@gmail.com)

Shanghai General Hospital Department of Orthopaedics: Shanghai Jiaotong University First People's Hospital Department of Orthopaedics https://orcid.org/0000-0001-8100-5097

\section{Research Article}

Keywords: Local Anesthesia, Tourniquet, Electro-cauterization, Wide-Awake, Hand Surgery

Posted Date: September 7th, 2021

DOI: https://doi.org/10.21203/rs.3.rs-816248/v1

License: () (1) This work is licensed under a Creative Commons Attribution 4.0 International License. Read Full License 


\section{Abstract}

Background : The purpose of this study is to illustrate whether the electro-cauterization and transient tourniquet enhanced efficiency of local anesthesia with epinephrine in surgery of metacarpal fractures.

Methods : Forty-four consecutive cases of metacarpal fractures with estimated major operative time more than 30 minutes were enrolled. Local anesthesia with epinephrine, electro-cauterization and transient tourniquet were performed. Data regarding anesthesia effect, bleeding in the surgical field (with inflating and deflating tourniquet), time when patient felt uncomfortable with tourniquet, inspection of the surgical outcome, and some other surgical tricks were collected and evaluated.

Results : All patients felt no pain for whole surgical period in the surgical field. Time when patient felt uncomfortable with tourniquet was about 16 minutes. Mean tourniquet time was about 29 minutes. There was no or less bleeding in the surgical field for whole surgical period. The anatomical structures, such as nerve, tendon and vessel can be easily distinguished and dissected. Outcome of repair and reconstruction could be examined with instructed movement. Postoperative inspection showed no symptom of inflammation.

Conclusions : Local anesthesia with epinephrine, electro-cauterization and transient tourniquet for major hand surgery can save time and obtain wide-awake effect, which would satisfy both doctors and patients.

\section{Introduction}

Surgeries in the finger and hand usually need a tourniquet to obtain a bloodless field to facilitate discerning the detail of the delicate structures (nerves, vessels and tendons) ${ }^{1,2,3}$. Sedation, Bier block, brachial plexus block, or general anesthesia would be performed to enhance the patients' endurance of the uneasy of the tourniquet compression ${ }^{4}$, which would make the patients unable to cooperatively move the reconstructed hand and finger structures intraoperatively. Since the myth, epinephrine when injected into the fingers, nose, ears, and toes would cause infarction in body parts with end arteries, was found to be not valid. Lidocaine with epinephrine has become more popular for routine hand surgery ${ }^{5,6}$. In fact, the extremely acidic procaine induces the tissue necrosis, and phentolamine can reverse the vasoconstrictive effect of epinephrine ${ }^{7}$. Even the high concentrated epinephrine of 1:1000 injected into fingers voluntarily or accidentally never cause a finger death ${ }^{8}$. Local anesthesia of lidocaine and epinephrine could satisfy most hand surgery under no tourniquet control, which now named as wide awake local anesthesia no tourniquet (WALANT) 9,10,11,12. However, there has to be about 25 minutes interval from epinephrine injected to hemostasis effect available for surgery ${ }^{13}$, which means low efficiency in some developing countries where hand trauma frequently occurs. Recent report showed that tourniquets for short wide-awake procedures are feasible and well accepted ${ }^{14}$. We hypothesized, in relatively long surgery such as metacarpal fractures, that with the help of electro-cauterization and transient tourniquet, local anesthesia with epinephrine could yield the same wide awake effect and save the time.

\section{Material And Methods}

We did surgery (open reduction and internal fixation, ORIF) in metacarpal fractures of 50 consecutive cases from 2020 in our unit, six of which were excluded for the general anesthesia (Table 1). Our hospital ethics committee approved this study (2020 KY234). The patient was hospitalized one day before surgery or at the surgery day, and was discharged one day after surgery, according to our hospital policy. The institutional review board of our hospital approved this study. Generally, the ORIF was performed whenever some special preparation (mostly hardware sterilized) completed. 
Table 1

Patients' Data

\begin{tabular}{|c|c|c|c|c|c|c|c|c|c|}
\hline $\begin{array}{l}\text { Case } \\
\text { No }\end{array}$ & Sex & $\begin{array}{l}\text { Age } \\
\text { (yrs) }\end{array}$ & Fx type \& Treatment & $\begin{array}{l}\text { Electro- } \\
\text { cautery } \\
\text { setup } \\
\text { time } \\
\text { (mm:ss) }\end{array}$ & $\begin{array}{l}\text { Uncomfortable with } \\
\text { toumiquet } \\
\text { staring time } \\
\text { (mm:ss) }\end{array}$ & $\begin{array}{l}\text { Tourniquet } \\
\text { Release } \\
\text { time } \\
\text { (mm:ss) }\end{array}$ & $\begin{array}{l}\text { Operation } \\
\text { Time } \\
\text { (hh:mm) }\end{array}$ & $\begin{array}{l}\text { Surgical } \\
\text { field } \\
\text { bleeding }\end{array}$ & $\begin{array}{l}\text { Delicate dissection } \\
\text { completed, when } \\
\text { Tourniquet } \\
\text { Released }\end{array}$ \\
\hline 1 & $\mathrm{~F}$ & 24 & $1 \mathrm{~B}+4 \mathrm{~S}$, Plate + K-wire & $2: 15$ & $18: 30$ & $30: 48$ & $2: 20$ & Less & 1B K-wire \\
\hline 2 & $M$ & 36 & 5B, Plate + K-wire & $2: 00$ & $10: 10$ & $28: 04$ & $1: 12$ & Less & K-wire \\
\hline 3 & $\mathrm{~F}$ & 51 & L1B, Plate + K-wire & $2: 08$ & $16: 40$ & $26: 45$ & $0: 50$ & Less & K-wire \\
\hline 4 & M & 33 & R5N, Plate & $1: 58$ & $19: 25$ & $28: 15$ & $1: 05$ & Less & K-wire \\
\hline 5 & $\mathrm{~F}$ & 60 & L4S, Plate & $2: 05$ & $17: 35$ & $32: 55$ & $1: 45$ & Less & Plate \\
\hline 6 & M & 27 & R5N, Plate & $2: 16$ & $15: 05$ & $30: 33$ & $1: 20$ & Less & K-wire \\
\hline 7 & M & 45 & $\begin{array}{l}\text { R2S + R3S, Plate + } \\
\text { Cannula screw }\end{array}$ & $2: 00$ & $17: 16$ & $35: 22$ & $1: 40$ & Less & R3S, Plate \\
\hline 8 & $M$ & 31 & L5S, Plate & $2: 03$ & $15: 01$ & $25: 15$ & $1: 30$ & Less & Plate \\
\hline 9 & $M$ & 49 & L2S, Plate & $2: 09$ & $12: 53$ & $29: 15$ & $2: 00$ & Less & Plate \\
\hline 10 & $\mathrm{~F}$ & 49 & L3S, Plate & $1: 50$ & $13: 50$ & 19:05 & $2: 10$ & & \\
\hline 11 & $M$ & 49 & R1B, Plate & $2: 26$ & $15: 48$ & $28: 14$ & $1: 49$ & Less & K-wire \\
\hline 12 & $\mathrm{~F}$ & 49 & R1B, Plate & $2: 10$ & $11: 29$ & $18: 10$ & $1: 30$ & & \\
\hline 13 & $M$ & 51 & L5B, Plate + K-wire & $2: 01$ & $16: 00$ & $36: 22$ & $2: 19$ & Less & K-wire \\
\hline 14 & M & 57 & L1B, Plate + K-wire & $2: 15$ & $19: 11$ & $30: 51$ & $1: 55$ & Less & K-wire \\
\hline 15 & $\mathrm{~F}$ & 64 & L4S, Plate & $2: 08$ & $16: 20$ & $30: 48$ & $1: 10$ & Less & Plate \\
\hline 16 & $M$ & 25 & R5N, Plate & $2: 10$ & $12: 31$ & $27: 12$ & $1: 05$ & Less & K-wire \\
\hline 17 & $M$ & 29 & R5B, Plate & $2: 12$ & $21: 36$ & $25: 24$ & $1: 35$ & Less & K-wire \\
\hline 18 & M & 29 & L3S, Plate & $2: 07$ & $15: 40$ & $25: 00$ & $0: 45$ & Less & Plate \\
\hline 19 & $M$ & 55 & R5S, Plate & $1: 59$ & $19: 55$ & $28: 29$ & $2: 00$ & Less & Plate \\
\hline 20 & $M$ & 21 & L5S, Plate & $1: 51$ & $12: 42$ & $35: 33$ & $1: 35$ & Less & Plate \\
\hline 21 & $\mathrm{~F}$ & 56 & R5N, Plate & $2: 21$ & $18: 32$ & $30: 49$ & $0: 35$ & Less & K-wire \\
\hline 22 & M & 19 & R5S, Plate & $2: 24$ & $22: 16$ & $33: 10$ & $0: 45$ & Less & Plate \\
\hline 23 & $M$ & 43 & R5S, Plate & $2: 05$ & $11: 31$ & $31: 18$ & $1: 00$ & Less & Plate \\
\hline 24 & $\mathrm{~F}$ & 31 & L2N, Plate & $2: 08$ & $17: 31$ & $26: 43$ & $1: 25$ & Less & K-wire \\
\hline 25 & $\mathrm{~F}$ & 33 & L5S, Plate & $2: 20$ & $16: 09$ & $33: 49$ & $1: 30$ & Less & Plate \\
\hline 26 & $M$ & 32 & R4S, Plate & $1: 55$ & $11: 05$ & $29: 30$ & $1: 30$ & Less & Plate \\
\hline 27 & $M$ & 46 & R5S, Plate & $2: 24$ & $15: 23$ & $29: 10$ & $1: 55$ & Less & Plate \\
\hline 28 & $M$ & 27 & R5N, Plate & $2: 09$ & $21: 19$ & $35: 05$ & $1: 04$ & Less & K-wire \\
\hline 29 & $M$ & 28 & L3S, Plate & $2: 20$ & $12: 45$ & $30: 55$ & $1: 35$ & Less & Plate \\
\hline 30 & M & 20 & R5N, Plate & $1: 54$ & $21: 20$ & $34: 30$ & $1: 15$ & Less & K-wire \\
\hline 31 & M & 51 & L2S, Plate & $1: 57$ & $18: 14$ & $27: 45$ & $1: 05$ & Less & Plate \\
\hline 32 & $M$ & 55 & R1B, Plate + K-wire & $2: 03$ & $14: 33$ & $25: 40$ & $1: 50$ & Less & K-wire \\
\hline 33 & M & 54 & $\begin{array}{l}\text { L3B + L4B, Plate + K- } \\
\text { wire }\end{array}$ & 2:05 & $13: 41$ & $33: 55$ & $2: 30$ & Less & $\mathrm{L} 3 \mathrm{~B}+\mathrm{L} 4 \mathrm{~B}, \mathrm{~K}$-wire \\
\hline 34 & $\mathrm{~F}$ & 48 & R1B, Plate + K-wire & $2: 18$ & $16: 09$ & $29: 20$ & $0: 55$ & Less & K-wire \\
\hline 35 & M & 20 & R1B, Plate + K-wire & $1: 53$ & $20: 01$ & $25: 06$ & $0: 45$ & Less & K-wire \\
\hline 36 & $M$ & 34 & L5B, Plate + K-wire & $2: 18$ & $15: 09$ & $33: 34$ & $1: 00$ & Less & K-wire \\
\hline
\end{tabular}

*1 = first metacarpus, 2 = second metacarpus, 3 = third metacarpus, $4=$ fourth metacarpus, $5=$ fifth metacarpus. $\mathrm{B}=$ base, $\mathrm{S}=$ shafts, $\mathrm{N}=\mathrm{Neck}$. 


\begin{tabular}{|c|c|c|c|c|c|c|c|c|c|}
\hline $\begin{array}{l}\text { Case } \\
\text { No }\end{array}$ & Sex & $\begin{array}{l}\text { Age } \\
\text { (yrs) }\end{array}$ & Fx type \& Treatment & $\begin{array}{l}\text { Electro- } \\
\text { cautery } \\
\text { setup } \\
\text { time } \\
\text { (mm:ss) }\end{array}$ & $\begin{array}{l}\text { Uncomfortable with } \\
\text { tourniquet } \\
\text { staring time } \\
\text { (mm:ss) }\end{array}$ & $\begin{array}{l}\text { Tourniquet } \\
\text { Release } \\
\text { time } \\
\text { (mm:ss) }\end{array}$ & $\begin{array}{l}\text { Operation } \\
\text { Time } \\
\text { (hh:mm) }\end{array}$ & $\begin{array}{l}\text { Surgical } \\
\text { field } \\
\text { bleeding }\end{array}$ & $\begin{array}{l}\text { Delicate dissection } \\
\text { completed, when } \\
\text { Tourniquet } \\
\text { Released }\end{array}$ \\
\hline 37 & M & 34 & R5B, Plate + K-wire & 2:09 & 17:05 & $27: 08$ & $1: 40$ & Less & K-wire \\
\hline 38 & M & 22 & $\begin{array}{l}\text { R4B + R5B, Plate + K- } \\
\text { wire }\end{array}$ & 2:19 & $12: 38$ & $24: 10$ & $2: 50$ & Less & R5B, K-wire \\
\hline 39 & M & 63 & L1B, Plate + K-wire & $2: 29$ & 22:17 & $25: 35$ & 2:05 & Less & K-wire \\
\hline 40 & M & 19 & L1B, Plate + K-wire & $1: 59$ & $13: 46$ & $26: 12$ & $1: 35$ & Less & K-wire \\
\hline 41 & M & 41 & L5B, Plate + K-wire & 2:07 & $15: 18$ & 29:42 & 1:15 & Less & K-wire \\
\hline 42 & M & 45 & R4S, Plate & $1: 56$ & $13: 27$ & $32: 42$ & $1: 00$ & Less & Plate \\
\hline 43 & M & 46 & R4S, Plate & $2: 26$ & $12: 06$ & $36: 34$ & $1: 10$ & Less & Plate \\
\hline 44 & $\mathrm{~F}$ & 63 & L5N, Plate + K-wire & 2:03 & $15: 20$ & $25: 45$ & $0: 56$ & Less & K-wire \\
\hline Mean & & & 2:08 & & $16: 00$ & 29: & & & \\
\hline SD & & & $0: 10$ & & 3:05 & $4: 1$ & & & \\
\hline
\end{tabular}

After hospitalized, the patient would be arranged for a conversation with a senior surgeon in detail on the anesthesia and the surgery, as followed. The local anesthesia was a kind of injection of lidocaine and epinephrine into the operative site, which was safe and no need of controlling the patient's condition, such as the blood hypertension and dysfunctions of heat, kidney, lung and brain. The patient could eat and drink as usual. Only onset-poke-pain like a mosquito sting would occur and the injected so-called narcotic drags would be little effect to the patient. The intraoperative transient tourniquet application with the aim to save time would be uncomfortable and no any harm to the patient, and we could release it at any time the patient was unable to endure. The whole procedure would be wide-awake and no any sedation, which could facilitate observing the surgical effect for surgeons and the patient at any operative step. The patient could be discharged after surgery. This conversation would be duplicated while the patient entering the operating room.

The tourniquet was banded to the $1 / 3$ upper part of the suffered upper limb. After sterilizing and draping, the operative site was injected the combined solution, $1 \%$ lidocaine with 1:100,000 epinephrine and soda ( $1 \mathrm{ml}$ of $8.4 \%$ bicarbonate added into $10 \mathrm{ml}$ of $1 \%$ lidocaine with 1:100,000 epinephrine to alleviate the acidity). We completely tracked Lalonde's recommendation to perform this anesthesia ${ }^{12}$. Then the electro-cauterization was set up to desiccate mode and power of 20 watts or less, and we preferred coagulation to dissect the tissue for its hemostasis effect, which would consume about 2 minutes. The tourniquet was inflated and the surgery was started. Only the epidermis was lanced with a scalpel, and the deeper tissue was dissected with the electro-cauterization. We pushed away and cut to separate the connect tissue with the thin, narrow and blunt blade of the electro-cauterization. Slightly wiping to eliminate some edema with gauze, we coagulated some visible vessels and could discern and protect some vital structures like nerves in the bloodless tissue. The metacarpal fracture was exposed reduced and temporarily fixed with Kirschner wire. Usually surgery for one metacarpal fracture till this step, the operative time would be 25 minutes more or less. We could release the tourniquet and took X-rays to monitor the reduction (Fig. 1). We would elongate the tourniquet to the next surgical steps, if the patient did not express unacceptable uneasy. The patients always felt uncomfortable with the tourniquet compression, and most of them could endure to finish of the reduction and temporary fixation. For a few patients unable to endure we released the tourniquet, and we could go on operating in some bloody field. Generally, 2 minutes after the tourniquet released, the patient felt easy and the motor function would recover, which could make the patient move his fingers cooperatively to observe the reconstructive effect. Till now, more than 25 minutes from the injection elapsed, the hemostatic effect of epinephrine came on and would last to the end of the rest procedure, such as metacarpal fracture fixed with plates and screws, concomitant injured structures repaired and reconstructed, and skin closed. Anyway, fractures should be aligned and fixed to satisfy the hand movement. We recorded the time at some spot of the surgical procedure and evaluated.

We conducted an experiment to elucidate specific experience with tourniquet compression, in which the author and his five close friends were involved. All was told the experimental aim and no permanent harm in advance. The lapsing time and feeling at some stage were record (Table 2). 
Table 2

Normal Volunteers' Experience with Tourniquet in Arm

\begin{tabular}{|c|c|c|c|c|c|c|c|c|c|c|c|c|}
\hline No & Gender & $\begin{array}{l}\text { Age } \\
\text { (yrs) }\end{array}$ & $\begin{array}{l}\text { Weight } \\
(\mathrm{Kg})\end{array}$ & $\begin{array}{l}\text { Heigth } \\
\text { (cm) }\end{array}$ & $\begin{array}{l}\text { Blood } \\
\text { Pressure }(\mathrm{mmHg})\end{array}$ & Occupation & $\begin{array}{l}\text { Forearm } \\
\text { width }(\mathrm{cm})\end{array}$ & $\begin{array}{l}\text { Uncomfortable } \\
\text { with } \\
\text { toumiquet } \\
\text { staring time } \\
\text { (mm:ss) }\end{array}$ & $\begin{array}{l}\text { Tourniquet } \\
\text { Release } \\
\text { time } \\
\text { (mm:ss) }\end{array}$ & $\begin{array}{l}\text { Sensation } \\
\text { starting } \\
\text { recovery } \\
\text { (mm:ss) }\end{array}$ & $\begin{array}{l}\text { Movement } \\
\text { starting } \\
\text { recovery } \\
\text { (mm:ss) }\end{array}$ & $\begin{array}{l}\mathrm{Fl} \\
\text { re } \\
\text { (n }\end{array}$ \\
\hline 1 & $M$ & 49 & 75.7 & 170 & $140 / 90$ & Doctor & 30.9 & $27: 28$ & $38: 01$ & $40: 08$ & $40: 04$ & 54 \\
\hline 2 & $M$ & 31 & 75.6 & 177 & $120 / 80$ & Doctor & 35.3 & $29: 53$ & $32: 23$ & $34: 54$ & $34: 87$ & 44 \\
\hline 3 & $\mathrm{~F}$ & 32 & 75.2 & 163 & $125 / 80$ & Engineer & 30.9 & $25: 46$ & $29: 45$ & $32: 48$ & $32: 08$ & 41 \\
\hline 4 & $\mathrm{~F}$ & 59 & 70.0 & 168 & $130 / 90$ & Teacher & 30.3 & $31: 03$ & $35: 21$ & $38: 44$ & 39:01 & 52 \\
\hline 5 & $\mathrm{~F}$ & 28 & 63.7 & 170 & $110 / 70$ & Nurse & 29.3 & $25: 45$ & $27: 35$ & $29: 45$ & $29: 89$ & 42 \\
\hline 6 & $M$ & 39 & 90.1 & 180 & $125 / 80$ & Manager & 31.8 & $26: 08$ & $28: 45$ & $31: 13$ & $31: 04$ & 47 \\
\hline
\end{tabular}

Descriptive statistics was used to collect and analyse the results.

\section{Results}

Tourniquet was released less than 25 minutes from injection in two cases. The time for setting up the electro-cauterization was about 2 minutes. All patients felt uncomfortable with the tourniquet compression, which started at about 16 minutes, released at 29 minutes less or more. Sensation and movement recovered in several minutes (we didn't record). All patients were able to move the finger and hand to inspect the reconstructive effect, according to the doctor's instruction. All patients kept wide awake during whole surgery, and expressed no complaint about the tourniquet application while inquiring after surgery. All surgery was performed successfully with no need of converting to another anesthesia and no too much bleeding was noted in the surgical field impeding dissection. Moreover, there was no obvious interval to wait the hemostatic effect of epinephrine, that is to say, we saved the time with this modified local anesthesia. Postoperative daily inspection and wound care showed normal, no extra edema and oozed secretion. Sutures were removed routinely on time.

\section{Discussion}

As Lalonde and some others experimented and illustrated, the prejudice regarding infarction in body parts with end arteries arisen from the vasoconstriction of epinephrine had been gradually rectified, which was eventually kind of tissue necrosis caused by the expired extremely acid procaine. Epinephrine was getting revived and its hemostatic effect could eliminate the tourniquet in surgery of the finger and hand. Without tourniquet, there would be no need of sedation, Bier block, brachial plexus block, or general anesthesia, which would keep the patient wide-awake to move his repaired or reconstructed structures subjectively during surgery $5,6,7,8,9,10,12$. Doctors could evaluate the surgical result for further treatment ${ }^{9,10,12}$, and patients' seeing of the recovery of normal movement could enhance their confidence in the post-operative rehabilitation. Moreover, local anesthesia was much more economical, rapid and efficient than the others, no need of anesthetists and no need of improvement some vital organs' malfunction ${ }^{12,14,15,16,17}$. Nowadays, wide awake local anesthesia no tourniquet (WALANT) was wide used in upper limb surgery, like fingers, hand, forearm and elbow ${ }^{18,19,20}$. However, it takes time for the epinephrine to constrict the vessels enough to form a less errhysis field for visual dissection. Bashir MM, et al found an interval of 25 minutes provides vastly superior operative field visibility ${ }^{13}$. In some developing countries, many employees without professional skill or the knowledge of system safety protection work overtime frequently, which would result in high incidence of hand injuries. Plus the other hand diseases, hand surgeons in these areas are very busy, and one team surgeons always have to do with 15 to 20 cases per operative day. 25 minutes per patient to wait for the hemostatic effect is definitely impracticable. For minor hand surgery of short time, we usually use the tourniquet to achieve a bloodless surgical view ${ }^{21,22}$. We hypothesized in complicated hand surgery with the electro-cauterization to speed we could complete the accurate dissection until the patients endurance of the tourniquet. And then, the left surgery could continue in a relatively less bleeding area with the epinephrine vasoconstriction. We could enjoy the benefit from wide-awake and timesaving of the local anesthesia with electro-cauterization and transient tourniquet for major surgery in hand.

Metacarpal fractures reduction should be very perfect. The most important intraoperative check is for the unacceptable rotational deformity, which usually affected adjacent fingers and caused significant cosmetic or functional problems. When flexed, two fingers would overlap to scissors-like interference, and surgical osteotomy could yield an ideal result ${ }^{23,24}$. Patients' subjectively flexing and extending the fingers to evaluate the repaired or reconstructed effect is of preference. The brachial plexus block and the general anesthesia with sedation are not suitable. WALANT is playing an important role instead of the ever-used Bier block.

A volunteers' experiment of small cases (two authors included, Table 2) with arm-tourniquet inflated to $250 \mathrm{mmHg}$ being conducted, we subjectively obtained our own feeling during whole procedure as followed. Sensation and movement of the distal zone to the tourniquet gradually disappeared from the proximal part to the distal end. Slight movement could exist a few seconds after the full sensation disappeared. When completely anesthesia, there still existed residue deep body sensation, which was a sort of blunt numbness if touch applied. This kind of uncommon feeling may sometimes frustrate the patient's endurance with the tourniquet. This may be the reason that two of our patients ended the tourniquet less than 25 minutes. There was no pain intolerance when we released the tourniquet. A few seconds later there always dramatically spasm feeling of the whole zone distal to the tourniquet and gradually disappeared, and the sensation and movement recovered. We recorded our experience as a preoperative conversation with the patient. 
In our consecutive cases, we performed the local anesthesia with electro-cauterization and transient Tourniquet. Twice preoperative thorough conversation with the patient could lessen his anxiety, we thought, especially in reassuring him that there would be no permanent hazard of transient tourniquet compression although uncomfortable. Our clinical data indicated that all patients recovered motion shortly after the tourniquet deflated and no any postoperative uneasy.

Electro-cauterization is widely used with two common modes of cut and coagulation to speed up in surgery ${ }^{25}$. With its power and the reaction extent precise adjusted, it could be used to dissect in flap surgery ${ }^{26}$. We found the 20 watts and desiccate mode of coagulation suitable for the watery tissue infiltrated with local anesthesia. With a tweezer acted as a reciprocal retractor and pincher, the high frequency electricity scalpel could incise, separate, and coagulate efficiently. We had to take time to ligate some visible vessels with tourniquet and no electro-cauterization, or vice versa, the bleeding usually blurred the view and stopped us from the precise dissecting. Intra-operative the gauze wiping might absorb some anesthesia solution, and it did not affect the hemostatic effect of epinephrine. Additionally, we found the surgical field was less bleeding with the epinephrine vasoconstriction and electro-cauterization (Figs. 2).

Some documents demonstrated a safe scale. In our cases, tourniquet was instantly inflated to $250 \mathrm{mmHg}$, and we did not set the respective pressure, with regard to individual situation, such as gender, age, body weight and blood pressure. Although tourniquet compression with $250 \mathrm{mmHg}$ of less than $30 \mathrm{minutes}$ was no harm to the tissue, we believed, less pressure, less uncomfortable, as illustrated by Lim E, et al ${ }^{27}$.

The hemostatic effect from epinephrine vasoconstriction is compulsory for the wide-awake surgery in the hand, although sometimes the major dissection is completed under the control of the tourniquet. Less time with the tourniquet compression, more comfortable and less potential harm to the tissue. Moreover, one reduction even to visually alignment for most metacarpal fractures could not suffice for the normal movements of finger, which could be from some little angulation or rotation of the fragments. The epinephrine vasoconstriction could lessen the amount and speed of bleeding and yield a clear field available for the further adjustment of the reduction and fixation, and the split tissue closing.

In this study, we performed the descriptive statistics, because some data were relatively subjective.

Despite of the uncomfortable and no permanent harm with transient tourniquet compression, the local anesthesia with electro-cauterization and epinephrine could save time and keep wide awake. This could be an optional for some hand surgeons in their favor.

\section{Declarations}

\section{Ethics statement:}

Written informed consent of patients and volunteers was obtained following a detailed explanation of the procedures that they may undergo. This study was approved by the ethics review committee of our hospital (No.2020ky234).

\section{Declaration of conflicting interest:}

The authors declare that there is no conflict of interest.

\section{Funding:}

This research received no specific grant from any funding agency in the public, commercial, or not-for-profit sectors.

\section{References}

1. Cox C, Yao J. Tourniquet usage in upper extremity surgery. J Hand Surg Am. 2010;35(8):1360-1.

2. Odinsson A, Finsen V. Tourniquet use and its complications in Norway. J Bone Joint Surg Br. 2006;88(8):1090-2.

3. Oragui E, Parsons A, White T, Longo UG, Khan WS. Tourniquet use in upper limb surgery. Hand NY. 2011;6(2):165-73.

4. Krackow KA. A manoeuvre for improved positioning of a tourniquet in the obese patient. Clin Orthop Relat Res. 1982;168:80-2.

5. Thomson CJ, Lalonde DH, Denkler KA. A critical look at the evidence for and against elective epinephrine use in the finger. Plast Reconstr Surg. 2007;119(1):260-6.

6. Lalonde $\mathrm{DH}$, Bell M, Benoit $\mathrm{P}$, et al. A multicenter prospective study of 3110 consecutive cases of elective epinephrine use in the fingers and hand: the Dalhousie Project clinical phase. J Hand Surg Am. 2005;30(5):1061-7.

7. Nodwell T, Lalonde DH. How long does it take phentolamine to reverse adrenaline-induced vasoconstriction in the finger and hand? A prospective randomized blinded study: the Dalhousie project experimental phase. Can J Plast Surg. 2003;11(4):187-90.

8. Fitzcharles-Bowe C, Denkler KA, Lalonde DH. Finger injection with high-dose (1:1000) epinephrine: does it cause finger necrosis and should it be treated? Hand NY. 2007;2(1):5-11.

9. Higgins A, Lalonde DH, Bell M, McKee D, Lalonde JF. Avoiding flexor tendon repair rupture with intraoperative total active movement examination. Plast Reconstr Surg. 2010;126(3):941-5.

10. Lalonde DH. Wide-awake flexor tendon repair. Plast Reconstr Surg. 2009;123(2):623-5.

11. Lalonde DH. “Hole-in-one” local anesthesia for wide-awake carpal tunnel surgery. Plast Reconstr Surg. 2010;126(5):1642-4. 
12. Lalonde DH. Reconstruction of the Hand with Wide Awake Surgery. Clin Plastic Surg. 2011;38(4):761-9.

13. Bashir MM, Qayyum R, Saleem MH, Siddique K, Khan FA. Effect of Time Interval Between Local Anesthesia Infiltration and Start of Surgery on Operative Field Visibility in Hand Surgery Without Tourniquet. J Hand Surg Am. 2015;40(8):1606-9.

14. Shulman BS, Rettig M, Yang SS, Sapienza A, Bosco J, Paksima N. Tourniquet Use for Short Hand Surgery Procedures Done Under Local Anesthesia Without Epinephrine. J Hand Surg Am. 2020; 45(6):554.e1-554.e6.

15. Steiner MM, Calandruccio JH. Use of Wide-awake Local Anesthesia No Tourniquet in Hand and Wrist Surgery. Orthop Clin North Am. 2018;49(1):63-8.

16. Lied L, Borchgrevink GE, Finsen V. Wide Awake Hand Surgery. J Hand Surg Asian Pac Vol. 2017;22(3):292-6.

17. Van Demark RE Jr, Becker HA, Anderson MC, Smith VJS. Wide-Awake Anesthesia in the In-Office Procedure Room: Lessons Learned. Hand (N Y). 2018; 13(4):481-485.

18. Tang JB, Gong KT, Zhu L, Pan ZJ, Xing SG. Performing Hand Surgery Under Local Anesthesia Without a Tourniquet in China. Hand Clin. 2017;33(3):41524.

19. Gong KT, Xing SG. How to establish and standardize wide-awake hand surgery: experience from China. J Hand Surg Eur. 2017;42(8):868-70.

20. Lalonde DH. Conceptual origins, current practice, and views of wide awake hand surgery. J Hand Surg Eur. 2017;42(9):886-95.

21. Walsh AC. The use of local anaesthetic with a tourniquet in surgery of the hand. Can Med Assoc J. 1954;70(5):539-41.

22. Bidwai AS, Benjamin-Laing HE, Shaw DA, Iqbal S, Jones WA, Brown DJ. Patient satisfaction with tourniquet application and local anaesthesia infiltration in carpal tunnel decompression and the relationship with overall satisfaction. J Plast Surg Hand Surg. 2013;47(6):481-3.

23. Bindra RR, Burke FD. Metacarpal Osteotomy for Correction of Acquired Phalangeal Rotational Deformity. J Hand Surg Am. 2009;34(10):1895-9.

24. Jawa A, Zucchini M, Lauri G, Jupiter J. Modified Step-Cut Osteotomy for Metacarpal and Phalangeal Rotational Deformity. J Hand Surg Am. 2009;34(10):335-40.

25. Vedbhushan ST, Mulla MA, Haroonrasid, Chandrashekhar DM. Surgical Incision by High Frequency Cautery. Indian J Surg. 2013;75(6):440-3.

26. Rousseau P, Vincent H, Potier B, Arnaud D, Darsonval V. Diathermocoagulation in cutting mode and large flap dissection. Plast Reconstr Surg. 2011;127(5):2093-8.

27. Lim E, Shukla L, Barker A, Trotter DJ. Randomized blinded control trial into tourniquet tolerance in awake volunteers. ANZ J Surg. 2015;85(9):636-8.

\section{Figures}

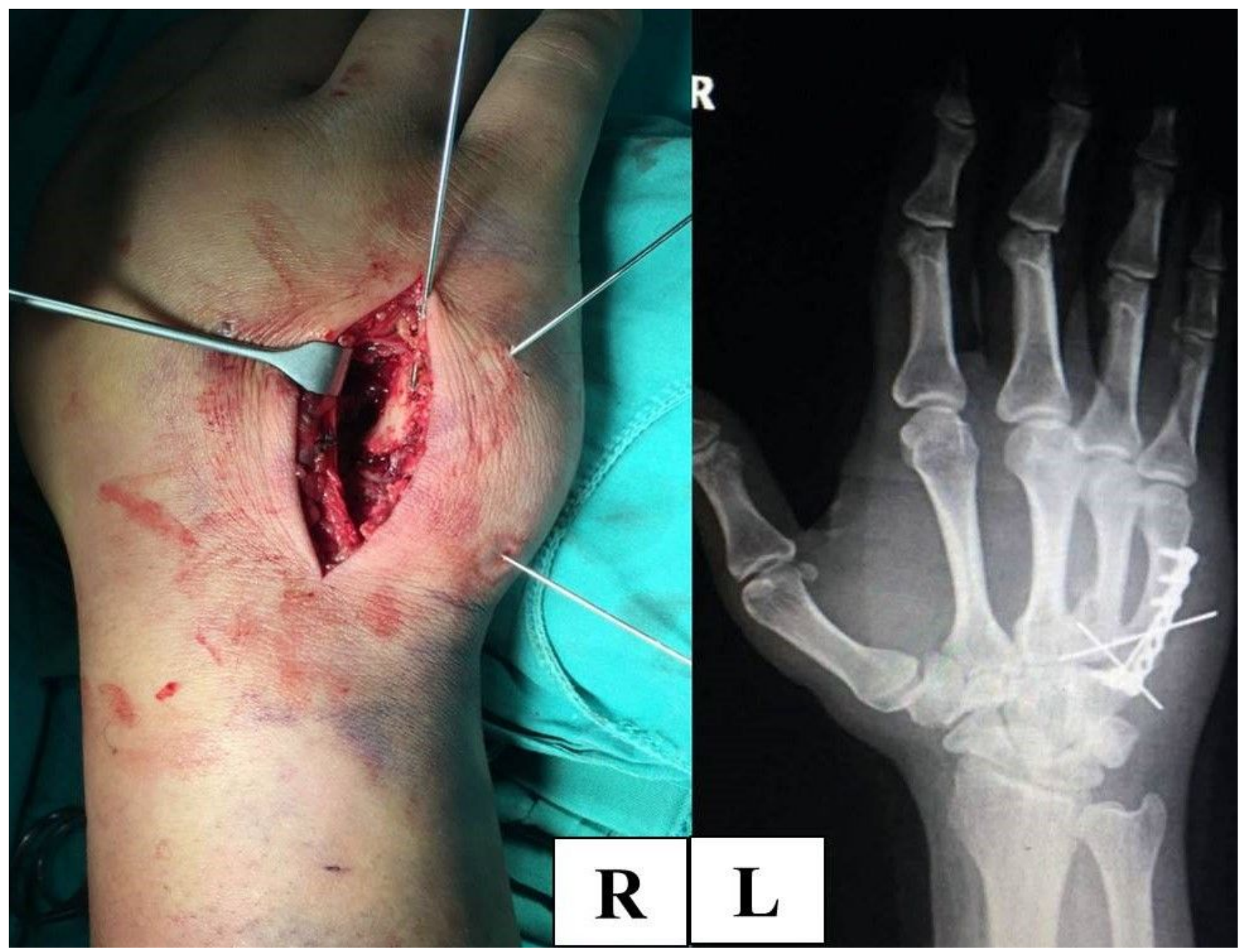




\section{Figure 1}

The base fracture of the fifth metacarpal bone. About 28 minutes was consumed, when surgery proceeded to three K-wires fixing the reduced fragments. The tourniquet was released, no apparently bleeding occurred (R). X-rays showed the anatomical alignment of the fractures, and the rational position of the implant (L).

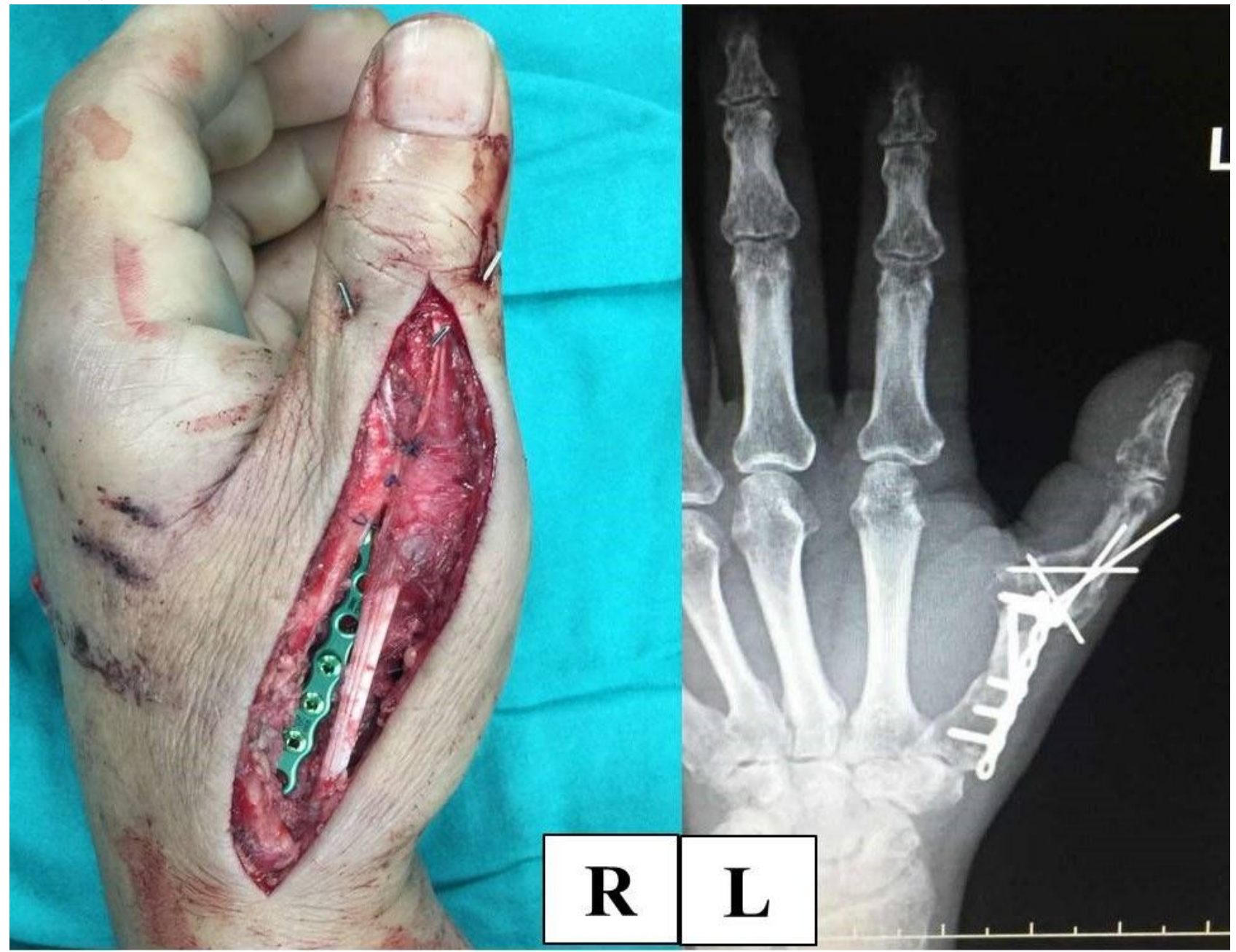

\section{Figure 2}

The shaft fracture of the first metacarpus. Mini-plate and screws were directly used to fix the reduced fragments. The tourniquet was released at about 32 minutes, no apparently bleeding occurred (R). X-rays showed the anatomical alignment of the fractures, and the rational position of the implant ( $\mathrm{L})$. This patient suffered the base fracture of the thumb proximal phalanx as well, and we fixed it with three K-wires. 